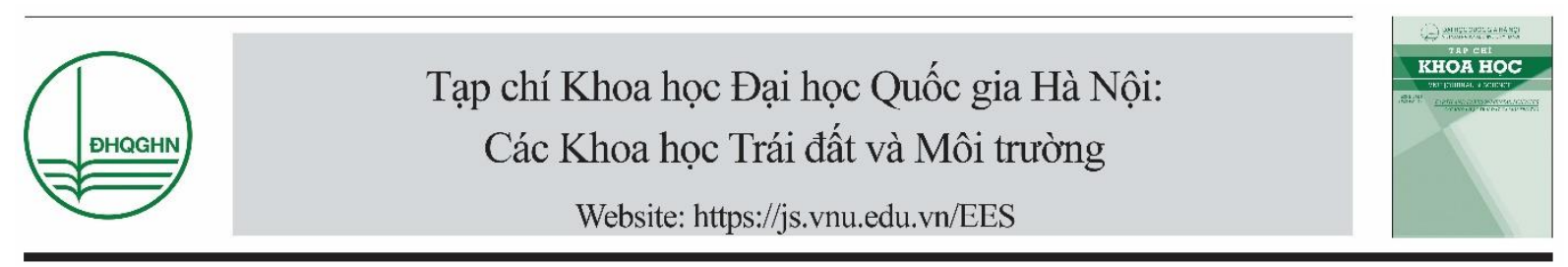

\title{
Ảnh hưởng của việc bổ sung nấm mốc phân huỷ lignin đến đặc tính và khả năng phân hủy Cartap của hỗn hợp sinh học
}

\author{
Lê Văn Thiện*, Đàm Thị Trung Hiếu, Lê Thị Thắm Hồng, \\ Nguyễn Phương Thảo, Ngô Thị Tường Châu \\ Khoa Môi truòng, Truòng Đại học Khoa học Tụ nhiên, ĐHQGHN, 334 Nguyễn Trãi, Hà Nội, Việt Nam
}

Nhận ngày 13 tháng 9 năm 2018

Chỉnh sửa ngày 07 tháng 11 năm 2018; Chấp nhận đăng ngày 04 tháng 12 năm 2018

\begin{abstract}
Tóm tắt: Đệm sinh học là một phương pháp đơn giản nhằm giảm thiểu ô nhiễm nguồn điểm trong quá trình thao tác với hoá chất bảo vệ thực vật. Trong đó hỗn hợp sinh học là yếu tố chính, quyết định đến hiệu quả phân huỷ của đệm sinh học. Mục đích của nghiên cứu này là đánh giá ảnh hưởng của việc bổ sung chủng nấm mốc có hoạt tính phân huỷ lignin cao, Penicillium chrysogenum N2, đến đặc tính sinh học và sự phân huỷ Cartap của hỗn hợp sinh học. Hỗn hợp sinh học đã được chuẩn bị với ba thành phần là rơm, bã thải trồng nấm và đất mặt với tî̉ lệ $2: 1: 1$, độ ẩm $60 \%$. Cartap được thêm vào hỗn hợp sinh học với hàm lượng $100 \mathrm{mgkg}^{-1}$. Kết quả nghiên cứu cho thấy, hoạt tính enzyme phân huỷ lignin của hỗn hợp sinh học được bổ sung nấm (đạt 645 đơn vị $\mathrm{kg}^{-1}$ ) cao hơn 8,5 lần so với đối chứng. Tương tự, các giá trị cao hơn ở công thức thí nghiệm đối với chỉ số hô hấp vi sinh vật $\left(455 \mathrm{mg} \mathrm{CO}_{2} 100 \mathrm{~g}^{-1}\right)$, mật độ của vi khuẩn tổng số $\left(6,5 \times 10^{8} \mathrm{CFU} \mathrm{g}^{-1}\right)$, xạ khuẩn tổng số $\left(1,3 \times 10^{8} \mathrm{CFUg}^{-1}\right)$, nấm mốc tổng số $\left(2,5 \times 10^{5} \mathrm{CFUg}^{-1}\right)$, vi sinh vật phân huỷ cellulose $\left(4,68 \times 10^{5} \mathrm{CFUg}^{-1}\right)$, hemi-cellulose $\left(3,5 \times 10^{5} \mathrm{CFUg}^{-1}\right)$ và lignin $\left(2,7 \times 10^{5} \mathrm{CFUg}^{-1}\right)$. Ngoài ra, hiệu quả phân huỷ Cartap ở $37^{\circ} \mathrm{C}$, độ ẩm $60 \%$ trong 10 ngày của hỗn hợp sinh học được bổ sung nấm là $99,42 \%$ cao hơn so với đối chứng là $75,35 \%$. Vì vậy việc sử dụng chủng nấm mốc có hoạt tính phân huỷ lignin cao, Penicillium chrysogenum N2, làm giống gây cấy có thể cải thiện được đặc tính sinh học cũng như hiệu quả phân huỷ Cartap của hỗn hợp sinh học trong hệ thống đệm sinh học.
\end{abstract}

Tù khoá: Đệm sinh học, hỗn hợp sinh học, phân huỷ Cartap, nấm mốc phân huỷ lignin, Penicillium chrysogenum.

\section{1. Đặt vấn đề}

Việc sử dụng hóa chất bảo vệ thực vật (HCBVTV) là một trong những chìa khóa để

\footnotetext{
*Tác giả liên hệ. ĐT: 84-916027871.

Email: levanthien@hus.edu.vn

https://doi.org/10.25073/2588-1094/vnuees.4296
}

đạt được sự thành công trong sản xuất nông nghiệp ở nước ta và trên thế giới. Tuy vậy, việc quản lý HCBVTV, đặc biệt từ các nguồn điểm, không phù hợp có thể dẫn đến sự ô nhiễm đất, nước mặt và nước ngầm. Một nguồn điểm gây ô nhiễm chính là sự tràn ra của HCBVTV trong khi đổ đầy, pha chế và làm sạch thiết bị bơm phun [1]. Trong khi đó, đệm sinh học được xem 
là một phương pháp đơn giản và chi phí thấp nhằm giảm thiểu ô nhiễm gây ra bởi nguồn điểm này. Hệ thống đệm sinh học ban đầu bao gồm ba hợp phần chính: (i) lớp sét (hoặc tấm lót) chống thấm ở đáy, (ii) hỗn hợp sinh học (HHSH) gồm đất mặt, rơm và than bùn với tỷ lệ $1: 2: 1$, và (iii) lớp cỏ trồng trên bề mặt. Hỗn hợp sinh học được xem là hợp phần quan trọng nhất của hệ thống đệm sinh học với (i) đất bề mặt cung cấp dung tích hấp phụ HCBVTV, chất mùn cho hoạt động của vi sinh vật và nguồn vi sinh vật phân huỷ HCBVTV, (ii) rơm cung cấp cơ chất chủ yếu cho hoạt động của vi sinh vật phân hủy HCBVTV, và (iii) than bùn góp phần điều chỉnh độ ẩm và $\mathrm{pH}$ [2]. Từ khi được ra đời tại Thụy Điển vào năm 1993, đệm sinh học đã nhận được sự quan tâm đặc biệt từ nhiều nước trên thế giới. Tính đến năm 2016, đã có khoảng 36 nước cho phép ứng dụng đệm sinh học vào xử lý dư lượng HCBVTV trong nông nghiệp [3]. Việc thiết kế đệm sinh học phụ thuộc vào điều kiện thực tế của mỗi nước như khí hậu, tập quán canh tác và đặc biệt là các nguồn nguyên liệu sẵn có [2]. Tuy vậy những nghiên cứu và ứng dụng như thế chưa được ghi nhận ở nước ta. Để góp phần khắc phục thực trạng này, bài báo sẽ đánh giá ảnh hưởng của việc bổ sung chủng nấm mốc có hoạt tính phân huỷ lignin cao, Penicillium chrysogenum N2, đến đặc tính và sự phân huỷ Cartap của hỗn hợp sinh học được chuẩn bị từ các nguồn nguyên liệu sẵn có tại địa phương gồm rơm rạ, bã thải trồng nấm và đất mặt.

\section{2. Đối tượng và phương pháp nghiên cứu}

\section{1. Đối tượng nghiên cứu}

- Hỗn hợp sinh học và các đặc tính sinh học của nó.

- Chủng nấm mốc có hoạt tính phân huỷ lignin cao, Penicillium chrysogenum N2.

- Hoá chất Cartap hydrochloride tinh khiết.

\subsection{Phuoong pháp nghiên cứu}

Phương pháp tuyển chọn chủng nấm mốc có hoạt tính phân huỷ lignin cao: Từ 6 chủng nấm mốc có hoạt tính phân hủy lignin trong bộ sưu tập giống sẵn có, cấy mỗi chủng vào môi trường Czapeck dịch thể có bổ sung lignin (Glucose $10 \mathrm{~g}$; Pepton $5 \mathrm{~g}$; $\mathrm{Na}_{2} \mathrm{HPO}_{4} 2,4 \mathrm{~g}$; $\mathrm{K}_{2} \mathrm{HPO}_{4} 2,0 \mathrm{~g} ; \mathrm{NH}_{4} \mathrm{NO}_{3} 0,1 \mathrm{~g} ; \mathrm{MgSO}_{4} 0,01 \mathrm{~g}$; $\mathrm{CaCl}_{2} 0,01 \mathrm{~g}$; lignin $1 \mathrm{~g}$; nước $1 \mathrm{~L}$ ) và nuôi cấy trên máy lắc ổn nhiệt (New Brunswick, Innova 44R, Eppendorf, Germany) ở 120 vòng/phút, $30^{\circ} \mathrm{C}$ trong vòng 6-7 ngày. Thu $10 \mathrm{~mL}$ dịch nuôi cấy, ly tâm ở 4.000 vòng/phút trong 20 phút, lọc qua màng lọc $0,45 \mu \mathrm{m}$ và xác định hoạt tính enzyme phân hủy lignin của dịch lọc theo phương pháp được trình bày sau đây.

Phương pháp định danh chủng nấm mốc được tuyển chọn: Chủng nấm mốc được định danh dựa vào các đặc điểm về hình thái khuẩn lạc và đặc điểm di truyền (trình tự nucleotide của gen $28 \mathrm{~S}$ rRNA). Việc phân tích trình tự nucleotide của gen $28 \mathrm{~S}$ rRNA được tiến hành theo các bước sau: (i) Chuẩn bị mẫu cấy thuần khiết, tách chiết DNA để thu nhận DNA bộ gen, đo nồng độ DNA bằng máy Biophotometer; (ii) Lấy 5 ul mẫu cho vào phản ứng PCR để khuếch đại đặc hiệu đoạn DNA dài 250 bp trên vùng gen $28 \mathrm{~S}$ rRNA bằng thiết bị $\mathrm{PCR}$ Thermal Cycler (Bio-Rad); (iii) Điện di sản phẩm PCR trên gel agarose $2 \%$, chụp hình bằng hệ thống Gel Doc (Bio-Rad); (iv) Tinh sạch sản phẩm $\mathrm{PCR}$ bằng bộ QIA quick PCR Purification Kit (QIAGEN); (v) Điện di sản phẩm đã tinh sạch bằng thiết bị Agilent 2100 Bioanalyzer; (vi) PCR SEQ sản phẩm đã tinh sạch trước khi giải trình tự trên hệ thống máy $\mathrm{ABI} 3130 \mathrm{XL}$; và (vii) Phân tích kết quả bằng phần mềm Sequecing analysis 5.3 và so sánh với dữ liệu sẵn có trên Genbank và ngân hàng dữ liệu NCBI bằng công cụ BLAST.

Phương pháp chuẩn bị hỗn hợp sinh học: (i) Chuẩn bị nguyên liệu: rơm thu từ đồng ruộng đất chiêm trũng ở Ninh Bình sau đó được cắt nhỏ với kích thước $2-3 \mathrm{~cm}$, bã thải trồng nấm sò trắng (Pleurotus eryngii) thu từ khu vực trồng nấm của Viện Di truyền Nông nghiệp Việt Nam ở Bắc Từ Liêm, Hà Nội và đất mặt $(0-20 \mathrm{~cm})$ thu từ vườn trồng rau ở Hà Đông, Hà Nội được để khô không khí, đồng nhất mẫu bằng cách cho qua rây $3 \mathrm{~mm}$; (ii) Phối trộn các nguyên liệu: rơm: bã thải trồng nấm: đất bề mặt theo tỷ lệ 1:2:1 (tổng khối lượng 2,5 kg); và (iii) 
Điều chỉnh độ ẩm đến $60 \%$ và ủ trong thời gian 0,15 và 30 ngày.

Phương pháp bổ sung chủng nấm mốc phân huỷ lignin vào hỗn hợp sinh học: (i) Nuôi cấy chủng nấm mốc trong vào môi trường Potato-Dextrose broth (Khoai tây $200 \mathrm{~g}$, Glucose $20 \mathrm{~g}$, nước cất $1 \mathrm{~L}, \mathrm{pH} 5,5)$ trên máy lắc ổn nhiệt (New Brunswick, Innova 44R, Eppendorf, Germany) ở $30^{\circ} \mathrm{C}, 120$ vòng/phút trong vòng 7 ngày; (ii) Bổ sung dịch nuôi cấy vào hỗn hợp sinh học với tỷ lệ $5 \%$ và trộn đều; và (iii) Điều chỉnh độ ẩm đến $60 \%$ và ủ trong thời gian 0 , 15 và 30 ngày.

Phương phá pbổ sung Cartap và thu mẫu cho các phân tích trong phòng thí nghiệm: Cartap được bổ sung vào các hồn hợp sinh học sau 15 ngày ủ (điều chỉnh độ ẩm $60 \%$ và $80 \%$ ) với hàm lượng cuối cùng là $100 \mathrm{mgkg}-1$ và lưu giữ trong 10 ngày ở các nhiệt độ $25^{\circ} \mathrm{C}$ và $37^{\circ} \mathrm{C}$. Mẫu được lấy ở 3 vị trí khác nhau (trên, giữa và dưới) của hỗn hợp sinh học, trộn đều để tạo mẫu tổ hợp.

Phưong pháp xác định hoạt tính enzyme phân hủy lignin: Sử dụng thử nghiệm MBTH/DMAB được mô tả chi tiết ở Castillo và cs. (1994) [4]. Thử nghiệm được dựa trên sự oxy hóa cặp đôi 3-methyl-2-benzothiazolinone hydrazone (MBTH) và 3-(dimethylamino) benzoic acid (DMAB). Hệ enzyme phân hủy lignin xúc tác hình thành một hợp chất có màu tím đậm với một độ hấp thụ cực đại tại bước sóng $590 \mathrm{~nm}$ trong sự có mặt của MBTH, $\mathrm{DMAB}$ và $\mathrm{MnSO}_{4}$. Phản ứng được khởi đầu bằng việc thêm vào dung dịch $\mathrm{H}_{2} \mathrm{O}_{2}$.

Phưong pháp xác định mật độ các nhóm vi sinh vật: Mật độ của các nhóm vi sinh vật được xác định bằng phương pháp đếm trên các đĩa thạch chứa môi trường và điều kiện nuôi cấy thích hợp: (i) vi khuẩn tổng số trên môi trường thạch-cao thịt-pepton, ở $30^{\circ} \mathrm{C}, 2-3$ ngày; (ii) xạ khuẩn tổng số trên môi trường Gause I, ở $30^{\circ} \mathrm{C}$ trong 5-7 ngày; (iii) nấm mốc tổng số trên môi trường Czapeck, ở $30^{\circ} \mathrm{C}$ trong 3-5 ngày; và (iv) vi sinh vật phân huỷ cellulose, hemicellulose và lignin trên môi trường muối khoáng tối thiểu $\left(\mathrm{Na}_{2} \mathrm{HPO}_{4} 2,4 \mathrm{~g}, \mathrm{~K}_{2} \mathrm{HPO}_{4} 2,0\right.$ g, $\mathrm{NH}_{4} \mathrm{NO}_{3} 0,1 \mathrm{~g}, \mathrm{MgSO}_{4} 0,01 \mathrm{~g}, \mathrm{CaCl}_{2} 0,01 \mathrm{~g}$ ) chứa $\mathrm{CMC}$, xylan và lignin tương ứng với hàm lượng $1 \mathrm{gL}^{-1}$, ở $^{\circ} 30^{\circ} \mathrm{C}, 7$ ngày.

Phưong pháp xác định hô hấp vi sinh vật: Hô hấp vi sinh vật được xác định dựa vào lượng khí $\mathrm{CO}_{2}$ sinh ra trong quá trình ủ mẫu hỗn hợp sinh học sử dụng phương pháp bẫy kiềm (alkaline trap method) theo Thompson (2002) [5].

Phương pháp xác định khả năng phân huy Cartap: Hàm lượng Cartap còn lại trong các mẫu được chiết xuất với dung dịch acetone acid hoá (acetone: nước cất: acid phosphoric đặc với tỷ lệ $98: 1: 1)$ bằng cách cân $5 \mathrm{~g}$ mẫu, thêm vào $30 \mathrm{~mL}$ dung dịch acetone acid hoá nói trên, đem lắc ở 350 vòng/phút trong 2 giờ ở nhiệt độ $25^{\circ} \mathrm{C}$, siêu âm trong 30 phút, ly tâm lạnh trong 5 phút ở 10.000 vòng/phút rồi đem lọc qua màng $0,2 \mu \mathrm{m}$ [4]. Hàm lượng Cartap được xác định bằng phương pháp sắc ký lỏng hiệu năng cao (HPLC). Hiệu quả phân hủy Cartap được tính bằng tỷ lệ phần trăm hàm hàm lượng Cartap còn lại trong mẫu so với hàm lượng ban đầu.

Phuơng pháp xử lý số liệu: Mỗi công thức thí nghiệm được lặp lại 3 lần. Số liệu được tính giá trị trung bình và xử lí bằng Microsoft Excel 2010 và HPLC Empower pro.

\section{Kết quả nghiên cứu và thảo luận}

3.1. Tuyển chọn và định danh chủng nấm mốc có hoạt tính phân huý lignin cao

Tiến hành xác định hoạt tính phân hủy lignin của 6 chủng nấm mốc (ký hiệu N1-N6), kết quả cho thấy chủng N2 có hoạt tính phân huỷ lignin cao nhất (đạt 173,6 đơn vị $\mathrm{L}^{-1}$ ). Vì vậy chủng N2 được chọn làm đối tượng cho các nghiên cứu tiếp theo. Chủng N2 có khuẩn lạc màu lục xanh, mặt dạng nhung, có các rãnh xuyên tâm không đều, mặt trái màu lục xanh đến đen, giá bào tử trần ngắn, có các nốt sần không nhẵn. Phân tích trình tự $28 \mathrm{~S}$ rRNA của chủng N2 cho thấy tương đồng $100 \%$ với trình tự đoạn gen $28 \mathrm{~S}$ rRNA của loài Penicillium 
chrysogenum (Hình 1). Vì vậy chủng N2 được xếp vào chi Penicillium, loài Penicillium chrysogenum và được định danh là Penicillium chrysogenum $\mathrm{N} 2$.

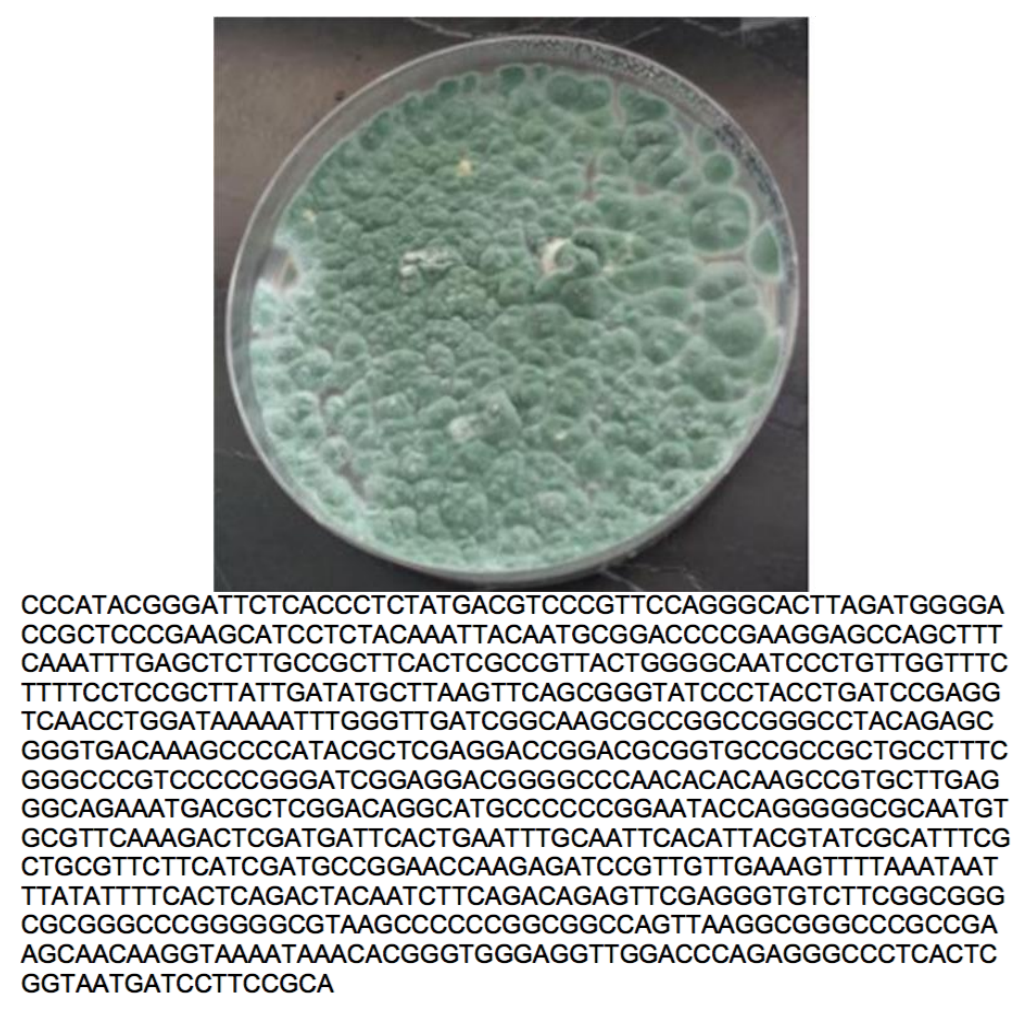

Hình 1. Hình thái khuẩn lạc trên đĩa thạch Czapeck và trình tự gen $28 \mathrm{~S}$ rRNA của chủng N2

\section{2. Đặc tính sinh hoc của hôn hợp sinh học}

\section{Hoạt tính enzyme phân hủy lignin}

Hệ enzyme phân hủy lignin bao gồm các enzyme laccase, lignin peroxidase và mangan peroxidase. Ngoài hoạt tính phân huỷ lignin, hệ enzyme này còn có khả năng phân huỷ các dị sinh chất ngoại lai nói chung và HCBVTV nói riêng [2]. Kết quả xác định hoạt tính enzyme phân hủy lignin của hỗn hợp sinh học được bổ sung nấm (HHSH thí nghiệm) và không được bổ sung nấm (HHSH đối chứng) tại các thời điểm 0,15 và 30 ngày ủ được thể hiện ở Bảng 1. Qua đó cho thấy hoạt tính enzyme phân hủy lignin của hỗn hợp sinh học sau khi ủ cao hơn so với trước khi ủ và 15 ngày là thời gian ủ tối ưu. Đồng thời tại thời điểm này, HHSH thí nghiệm có hoạt tính enzyme phân huỷ lignin cao gấp 8,5 lần so với HHSH đối chứng.
Bảng 1. Hoạt tính enzyme phân hủy lignin của hỗn hợp sinh học

\begin{tabular}{llll}
\hline \multirow{2}{*}{$\begin{array}{l}\text { Hoạt độ enzyme } \\
\left(\text { đơn vị } \mathrm{kg}^{1}\right)\end{array}$} & \multicolumn{3}{l}{ Thời gian ủ (ngày) } \\
\cline { 2 - 4 } & 0 & 15 & 30 \\
\hline $\begin{array}{l}\text { HHSH thí } \\
\text { nghiệm }\end{array}$ & 384,9 & 645,3 & 550,9 \\
$\begin{array}{l}\text { HHSH đối } \\
\text { chứng }\end{array}$ & 52,8 & 75,5 & 60,4 \\
\hline
\end{tabular}

Mật độ các nhóm vi sinh vật

Mật độ của các nhóm vi sinh vật tổng số và phân huỷ trong các hỗn hợp sinh học sau thời gian ủ tối ưu là khá phong phú, tuy nhiên ở HHSH thí nghiệm là cao hơn so với HHSH đối chứng (Bảng 2). Qua đó cho thấy việc bổ sung chủng nấm mốc có hoạt tính phân huỷ lignin cao đã tạo điều kiện thuận lợi cho sự sinh trưởng, phát triển của các nhóm vi sinh vật trong hỗn hợp sinh học. 
Bảng 2. Mật độ của các nhóm vi sinh vật trong hỗn hợp sinh học

\begin{tabular}{lllllll}
\hline \multirow{2}{*}{$\begin{array}{l}\text { Hỗn hợp } \\
\text { sinh học }\end{array}$} & \multicolumn{2}{l}{ Mật độ vi sinh vật tổng số } & $\left(10^{5} \mathrm{CFUg}^{-1}\right)$ & \multicolumn{3}{l}{ Mật độ vi sinh vật phân huỷ $\left(10^{5} \mathrm{CFUg}^{-1}\right)$} \\
\cline { 2 - 7 } Vi khuâ̂n & Xạ khuần & Nấm mốc & Cellulose & Hemi-cellulose & Lignin \\
\hline Thí nghiệm & $6,5 \times 10^{3}$ & $1,3 \times 10^{3}$ & 2,5 & 4,68 & 3,5 & 2,7 \\
Đối chứng & $5,7 \times 10^{3}$ & $0,26 \times 10^{3}$ & 1,0 & 1,89 & 2,15 & 1,78 \\
\hline
\end{tabular}

\section{Hô hấp vi sinh vật}

Khí $\mathrm{CO}_{2}$ không chỉ được sinh ra từ quá trình hô hấp hiếu khí của vi sinh vật mà còn từ hoạt động khoáng hóa chất hữu cơ trong hỗn hợp sinh học. Vì vậy, một chỉ số hô hấp cao đại diện cho một hệ vi sinh vật phong phú với hoạt tính sinh học mạnh mẽ. Trong nghiên cứu này, hô hấp vi sinh vật của HHSH thí nghiệm sau 15 ngày ủ (455 mg CO $\left.\mathrm{CO}_{2} 100 \mathrm{~g}^{-1}\right)$ cao hơn so với HHSH đối chứng (446 mg $\left.\mathrm{CO}_{2} 100 \mathrm{~g}^{-1}\right)$ và HHSH được chuẩn bị bởi Fernández-Alberti (2012) (308 mg CO $\left.2100 \mathrm{~g}^{-1}\right)[6]$.

\subsection{Khả năng phân huỷ Cartap của hôn hợp sinh hoc}

Sau khi được bổ sung vào hỗn hợp sinh học, hàm lượng Cartap giảm dần theo thời gian do hoạt động phân hủy của vi sinh vật đặc biệt là nhóm vi sinh vật phân hủy lignin. Bên cạnh đó, hiệu quả phân hủy Cartap có sự phụ thuộc vào độ ẩm và nhiệt độ phân hủy của hồn hợp sinh học. Điều này phù hợp với nhận định của Castillo và Torstensson (2007) khi cho rằng sự phân huỷ HCBVTV chịu ảnh hưởng của thành phần, độ ẩm của đệm sinh học và nhiệt độ của phân huỷ [7]. Ở độ ẩm $60 \%$ và nhiệt độ $37^{\circ} \mathrm{C}$, sự phân hủy Cartap của hỗn hợp sinh học cao hơn so với ở độ ẩm $80 \%$ và nhiệt độ $25^{\circ} \mathrm{C}$. Hiệu quả phân hủy Cartap của HHSH thí nghiệm là cao hơn so với HHSH đối chứng và đạt đến $99,42 \%$ tại độ ẩm $60 \%$, nhiệt độ $37^{\circ} \mathrm{C}$ sau 10 ngày bổ sung Cartap (Bảng 3 ). Kết quả này cho thấy việc bổ sung chủng nấm mốc có hoạt tính phân huỷ lignin cao đã giúp cải thiện hoạt động phân hủy Cartap bởi các nhóm vi sinh vật trong hỗn hợp sinh học và điều kiện tối thích về độ ẩm và nhiệt độ cho quá trình phân hủy Cartap của $\mathrm{HHSH}$ là $60 \%$ và $37^{\circ} \mathrm{C}$.
Bảng 3. Hiệu quả phân huỷ Cartap của hỗn hợp sinh học tại các độ ẩm và nhiệt độ khác nhau

\begin{tabular}{lllll}
\hline $\begin{array}{l}\text { Độ ẩm của hỗn } \\
\text { hợp }(\%)\end{array}$ & 60 & & 80 & \\
\hline $\begin{array}{l}\text { Nhiệt độ phân } \\
\text { hủy }\left({ }^{\circ} \mathrm{C}\right)\end{array}$ & 25 & 37 & 25 & 37 \\
$\begin{array}{l}\text { Hiệu quả phân } \\
\text { hủy của HHSH } \\
\text { thí nghiệm (\%) }\end{array}$ & 97,14 & 99,42 & 89,12 & 91,98 \\
$\begin{array}{l}\text { Hiệu quả phân } \\
\text { hủy của HHSH } \\
\text { đối chứng }(\%)\end{array}$ & 56,33 & 60,54 & 95,34 & 96,62 \\
\hline
\end{tabular}

\section{Kết luận}

1. Đã tuyển chọn và định danh được chủng nấm mốc Penicillium chrysogenum N2 có hoạt tính phân huỷ lignin cao nhất (đạt 173,6 đơn vị $\left.\mathrm{L}^{-1}\right)$ từ 6 chủng có hoạt tính phân huỷ lignin trong bộ sưu tập giống sẵn có.

2. Đã tạo được các hỗn hợp sinh học từ các nguyên liệu sẵn có tại địa phương gồm, rơm: bã thải trồng nấm sò trắng: đất mặt (theo tỷ lệ $2: 1: 1)$ với độ ẩm đạt $60 \%$ sử dụng để bố trí thí nghiệm bổ sung chủng nấm mốc Penicillium chrysogenum $\mathrm{N} 2$ được tuyển chọn nhằm xử lý hóa chất bảo vệ thực vật Cartap.

3. Đặc tính sinh học của hỗn hợp sinh học thí nghiệm sau thời gian ủ tối ưu 15 ngày có (i) hoạt độ enzyme phân hủy lignin đạt đển 645,28 đơn vị $\mathrm{kg}^{-1}$; (ii) mật độ các nhóm vi sinh vật tổng số như vi khuẩn, xạ khuẩn và nấm mốc lần lượt là $6,5 \times 10^{8}, 1,3 \times 10^{8}$ và $2,5 \times 10^{5} \mathrm{CFUg}^{-1}$, mật độ của các nhóm vi sinh vật phân hủy ligno-cellulose như vi sinh vật phân huỷ cellulose, hemi-cellulose và lignin tương ứng là $4,68 \times 10^{5}, 3,5 \times 10^{5}$ và $2,7 \times 10^{5} \mathrm{CFUg}^{-1}$; và (iii) chỉ số hô hấp vi sinh vật là $455 \mathrm{mg} \mathrm{CO} 2100 \mathrm{~g}^{-1}$. 
Đặc tính sinh học này của HHSH thí nghiệm là thuận lợi cho hoạt động phân hủy Cartap.

4. Hiệu quả phân hủy Cartap của hỗn hợp sinh học thí nghiệm cao nhất ở các điều kiện độ ẩm là $60 \%$, nhiệt độ là $37^{\circ} \mathrm{C}$, thời gian là 10 ngày và đạt đến $99,42 \%$. Việc bổ sung chủng nấm mốc Penicillium chrysogenum N2 có hoạt tính phân huỷ lignin cao vào hỗn hợp sinh học đã góp phần tạo ra một hỗn hợp sinh học có tiềm năng sử dụng để xử lý Cartap từ các nguồn điểm tại các vùng canh tác nông nghiệp.

\section{Lời cảm ơn}

Nghiên cứu này được tài trợ bởi Đại học Quốc gia Hà Nội trong đề tài mã số QG.18.13

\section{Tài liệu tham khảo}

[1] N.H. Spliid, W. Brusch, O.S Jacobsen, S.U Hansen. In Pesticide point sources and dispersion of pesticides from a site previously used for handling of pesticides, $16^{\text {th }}$ Danish Plant
Protection Conference, Side effects of pesticides, Weeds, 1999; pp 33-46.

[2] M.D.P. Castillo, L. Torstensson, J. Stenström, Biobeds for Environmental Protection from Pesticide Uses- A Review, Journal of Agricultural and Food Chemistry 56 (2008) 6206.

[3] J. Husby, Biobeds in the world, $5^{\text {th }}$ European Biobed Workshop, Throws Farm, UK, 2016.

[4] M.D.P Castillo, J. Stenström, P. Ander, Determination of manganese peroxidase activity with 3-methyl-2- benzothiazolinone hydrasone and 3-(dimethylamino) benzoic acid. Analytical Biochemistry 218 (1994) 399.

[5] W.H. Thompson, Test methods for the examination of composting and compost, U.S Composting Council and Department of Agriculture, U.S. Government Printing Office, Washington DC, 2002.

[6] S. Fernández-Alberti,O. Rubilar, G.R. Tortella, M.C. Diez1, Chlorpyrifos degradation in a Biomix: Effect of pre-incubation and water holding capacity, Journal of Soil Science and Plant Nutrition 12 (4) (2012) 785.

[7] M.D.P Castillo, L.Torstensson, Effect of biobed composition, moisture and temperature on the degradation of pesticides, Journal of Agricultural and Food Chemistry 55 (2007) 5725.

\title{
Effect of Inoculation with Ligninolytic Fungus on the Biological Activities and Cartap Degradation of Biomix
}

\author{
Le Van Thien, Dam Thi Trung Hieu, Le Thi Tham Hong, \\ Nguyen Phuong Thao, Ngo Thi Tuong Chau \\ Faculty of Environmental Sciences, VNU University of Science, \\ 334 Nguyen Trai, Thanh Xuan, Hanoi, Vietnam
}

\begin{abstract}
Biobed is a simple method to minimize point source contamination during manipulation of pesticides. The biomix is a principal element controlling the degradation efficacy of the biobed. The aim of this research was to evaluate the effect of inoculation with ligninolytic fungus Penicillium chrysogenum $\mathrm{N} 2$ on the biological activities and cartap degradation of biomix. Tests were made using biomixprepared with rice straw, spent mushroom substrate and top soil in a volumetric pro-portion of 2:1:1, moisture content of $60 \%$ and pre-incubation time of 15 days; cartap was added to the biomix at concentration of $100 \mathrm{mgkg}^{-1}$. The results demonstrated that the ligninolytic enzyme activity in the inoculated biomix $\left(645 \mathrm{U} \mathrm{kg}^{-1}\right)$ was 8.5 - fold higher compared with the non-inoculated one. Also, the
\end{abstract}


higher microbial respiration $\left(455 \mathrm{mg} \mathrm{CO}_{2} 100 \mathrm{~g}^{-1}\right)$ and counts of total aerobicbacteria $\left(6.5 \times 10^{8} \mathrm{CFUg}^{-1}\right)$, actinomyces $\left(1.3 \times 10^{8} \mathrm{CFUg}^{-1}\right)$, fungi $\left(2.5 \times 10^{5} \mathrm{CFUg}^{-1}\right)$, cellulolytic microrganisms $\left(4.68 \times 10^{5} \mathrm{CFUg}^{-1}\right)$, hemi-cellulolytic microrganisms $\left(3.5 \times 10^{5} \mathrm{CFU} \mathrm{g} \mathrm{g}^{-1}\right)$ andligninolytic microrganisms $\left(2.7 \times 10^{5} \mathrm{CFUg}^{-1}\right)$ were observed in the former. Besides, the Cartap degradation efficiency at $37^{\circ} \mathrm{C}$ for 10 days $(99.42 \%)$ was higher in the inoculated biomix compared with the non-inoculated one $(75.35 \%)$. In conclusion, it was recommended to use ligninolytic fungus Penicillium chrysogenum N2 as a inoculum to improve the biological activities and cartap degradation of biomix in biobed.

Keywords: Biobed, biomix, cartap degradation, ligninolytic fungus, Penicillium chrysogenum. 